\title{
Productivity Growth of Indian Manufacturing Sector: Panel Estimation of Stochastic Production Frontier and Technical Inefficiency
}

\author{
S.Madheswaran \\ Associate Professor
}

Institute for Social and Economic Change, Bangalore 560072

Badri Narayan Rath

Research Fellow

Institute for Social and Economic Change, Bangalore 560072

Hailin Liao

Dept. of Economics, Loughborough University, LE11 3TU, UK 


\begin{abstract}
Applying a Stochastic Production Frontier to sector-level data within manufacturing sector in India, this paper examines Total Factor Productivity (TFP) growth during 1979-80 to 1997-98. The analysis focuses on the trend of technical progress (TP) and Technical Efficiency Change (TEC). The stochastic frontier production function approach, applied in this paper, allows us to separate out these two components, and to identify productivity growth due to either improvement in efficiency or progress in technology. The most important difference between the frontier approach and the traditional index number approach to productivity growth analysis lies on assumption: the existence of an unobservable and idealized production possibility frontier with production-unit specific one-sided deviation from the frontier, i.e. explicitly allowing for inefficiency. If a production unit operates beneath the production frontier, then its distance from the maximal measures it's technical inefficiency. Hence, the frontier approach is capable of capturing both efficiency change and technological change as components of productivity change, which introduces an additional dimension to the analysis from the policy perspectives. The empirical result suggests that the total factor productivity growth in a large number of industries have improved during 1997-98 compared to 1980-81. TFP growth is mainly driven by technological progress not by technical efficiency change in case of Indian economy since all TECs are negative. In the light of empirical results, the policy implication is that the priority to boost economic growth should be in the enhancement of productivity based catching-up capability. In this direction, an efficiency oriented action plan aimed to improve productivity efficiency of manufacturing sector is required to be implemented for removing the fiscal and financial constraints faced by the enterprises which are located in industrially backward area.
\end{abstract}

JEL Classification Numbers: D24, L60, O30, O53, O47

Key words: Total Factor Productivity, Technical Efficiency change, Technological Progress, Stochastic Production Frontier, Indian Economy 


\section{Introduction}

India's post-independence development plans emphasized industrialization as very important instrument for sustained growth. The growth experience of Indian manufacturing industry from 1951 can be divided into three distinct sub-periods. These are 1951 to 1965 (the period of rapid industrial growth), 1965 to 1975 (the period of industrial deceleration or relative industrial stagnation) and finally the period from 1975 onwards (the period of recovery and acceleration). Inter temporal variations in the rates of growth of output in India's manufacturing sectors have been explained in a number of studies. Those studies were concerned with the marked deceleration in growth rate in Indian manufacturing experienced after the mid - sixties. The disappointing performance of the industrial sectors, therefore, forced policymakers to revise their policy tools. In the late 1970s, they started to implement some reforms such as " reducing the barriers to entry and expansion, simplifying procedures, and providing easier access to better technology and intermediate material imports", (Ahluwalia, 1991). There were some additional reforms during 1980s, but the most radical reforms were initiated since 1991, after the severe economic crisis in the fiscal year 1990/91. The major policy changes initiated in the industrial sector since July 1991 include removal of entry barriers, reduction of areas reserved exclusively for public sector, rationalization of approach towards monopolistic and restrictive practices, liberalization of foreign investment policy, far-reaching liberalization of import policy with respect to intermediate and capital goods, measures to bring about regional balance especially the development of backward areas and encouraging the growth of employment intensive small and tiny sector.

Today manufacturing activities, which account for nearly twenty percent of gross domestic product, form an integral part of Indian economy. Although manufacturing accounts for little over one fifth of total national output (GDP) and an even decline share 
of total employment, many economists argue that the economic health of manufacturing has important implications for the nation. Keeping in view the importance of the sector in terms of output and employment generation the thrust of the economic reforms has been to provide stimulus for further growth by targeting production for the global markets. The sector is thus expected to accelerate growth and launch the economy on a higher growth trajectory. Two pre-requisites, which are needed to fuel manufacturing growth, i.e., enhancement of productivity and competitiveness, have thus been the target of the recent policies towards this sector. It is well established that physical capital needs to be complimented by human capital in order to achieving higher levels of productivity and to competing in the global markets. Thus, increase in labor productivity, the critical determinant of overall productivity growth and competitiveness, have relevance in this era of market friendly policies to enhance growth.

A number of studies have been conducted in the manufacturing sector in India. Several studies like Ahluwalia (1991), Goldar (1986), Upender (1996), Sunil Kumar (2002), Aggarwal \& Kumar (1991), Balakrishnan \& Pushpangadan (1994), Mohan Rao (1996) have measured the productivity trends and growth of Indian manufacturing sector from post independence period. Most of the studies have discussed about the measurement of Total Factor Productivity (TFP) growth rate both at an aggregate and disaggregate level of Indian manufacturing sector. Similarly studies like (Joshi and Little, 1996; and Srinivasan, 1996) have examined the impact of the reforms on Indian manufacturing sector at an aggregate level. Mitra (1999) has used the methodology suggested by Cornwell et al. (1990) to study the technical efficiency and TFP growth in Indian industries. He uses panel data for the analysis, which covers 15 states and 17 two-digit industries for the period 1976-77 to 1992-93. A frontier production function is estimated for each of the industries using state-wise, year-wise panel data. Apart from the disaggregate study, he also estimated TFP at the all-India level. He used a twoinput framework (labour and capital) by using double-deflated value added. For this purpose, value of output and intermediate inputs has been deflated separately. His estimates show that in four industries (food products, beverages and tobacco products, basic metals and metal products) there has been a decline in TFPG in the later period 
(i.e. 1985-86 to 1992-93) as compared with the former (i.e., 1976-77 to 1984-85) in most or majority of the states. In other 13 industries, there has been an increase in TFPG in 1985-86 to $1992-93$ in most or majority of the states. This paper differs from the particular on the ground of it's specific focus attempt to explain a method to decompose the Total Factor Productivity (TFP) growth into technological progress and change in technical efficiency within the framework of the time varying coefficients frontier production function. The translog production function as used in this study, is more appropriate to describe production activities at the industry level, rather than aggregate country level.

The objective of this paper is to analyze technical efficiency change and the role of productivity change in economic growth by using stochastic production frontier to seventeen two-digit industry data within manufacturing from 1979-80 to 1997-98. Section 2 outlines the stochastic frontier production function methodology employed to measure rates of TFP growth. Section 3 provides description of the data and measurement framework used for productivity. In section 4, quantitative results have been presented. The final section summarises the main findings of the study.

\section{Methodology}

\subsection{Decomposition of TFP}

Output growth overtime is usually attributed to growth in inputs and improvement in total factor productivity. While measuring the sources of output growth, the contribution of TFP is always estimated as a residual, after accounting for the growth of inputs. If the industries operate on their production frontiers producing the maximum possible output or realizing the full potential of the technology, then that implies that improvement of productivity arises from technological progress. Operation on the frontier can be achieved if industries follow the best practice methods of application of technology commonly referred as technical efficiency. So productivity improvements can be achieved in two ways. One can either improves the state of technology by innovation, which is commonly, referred as technological progress. Alternatively one 
can implement procedures, such as improved workers education, to ensure workers use the existing technology more efficiently, known as technical efficiency.

Thus, the decomposition of total factor productivity can be introduced in the production function,

$$
y_{i t}^{F}=f\left(x_{i t}, t\right)
$$

Where $\mathrm{y}_{\mathrm{it}} \mathrm{F}$ is the potential output level on the frontier at time $\mathrm{t}$ for production unit $\mathrm{i}$, given technology $f($.$) and x_{i t}$ is a vector of inputs. Following Nishimizu \& Page (1982), a stochastic element can be introduced in the production function. Then any observed output $\mathrm{y}_{\mathrm{it}} \mathrm{using} \mathrm{x}_{\mathrm{it}}$ for inputs can be expressed as,

$$
y_{i t}=y_{i t}{ }^{F} \exp \left(-u_{i t}+v_{i t}\right)=f\left(x_{i t}, t\right) \exp \left(-u_{i t}+v_{i t}\right)
$$

Where $\left(u_{i t}+v_{i t}\right)$ is a composed error term combining output-based technical inefficiency $u_{i t}$, and a symmetric component $v_{i t}$ capturing random variation across production unit and random shocks that are external to its control. The derivative of the logarithm of equation (2) with respect to time is given by

$$
\dot{y}_{i t}=\frac{d \operatorname{Inf}\left(x_{i t}, t\right)}{d t}-\frac{d u_{i t}}{d t}+\frac{d v_{i t}}{d t}=T P+\sum_{j} \varepsilon_{j t} \frac{d x_{j t}}{d t}-\frac{d u_{i t}}{d t}
$$

From equation (3), it is evident that TFP growth consists of two components: technical progress and technical efficiency change.

\subsection{Model Specification}

The most commonly used tool of analysis for measuring technical efficiency is the frontier production function. In the neoclassical theory of production, the stochastic production function defines the maximum possible output of a firm for combinations of inputs and technology. The frontier approach is capable of capturing both efficiency change and technological change as components of productivity change. In order to analyze the technical efficiency change and role of productivity change in economic growth, we will consider the time-varying stochastic production frontier, originally proposed by Aigner, Lovell \& Schmidt (1977) in translog form as

$\ln y_{i t}=\alpha_{0}+\sum_{j} \ln x_{j i t}+\alpha_{l} t+\frac{1}{2} \sum_{j} \sum_{l} \beta_{j j l} \ln x_{j i t} \ln x_{l i t}+\frac{1}{2} \beta_{t t} t^{2}+\sum_{j} t \beta_{t j} \ln x_{j i t}+v_{i t}-u_{i t}--(4)$ 
In equation (4), $y_{i t}$ is the observed output, $t$ is the time variable and $x$ variables are inputs, subscripts $j$ and I index input. The efficiency error, $u$, accounting for production loss due to unit-specific technical inefficiency, is always greater than or equal to zero and assumed to be independent of the random error, v,which is assumed to have the usual properties ( $\sim$ iid $\left.N\left(0, \sigma_{v}{ }^{2}\right)\right)$.

Equation (4) can be rewritten as the following form,

$$
\begin{array}{r}
\operatorname{In} y_{i t}=\alpha_{t}+\alpha_{t} \ln L_{i}+\alpha_{k} \operatorname{In} K_{i}+\frac{1}{2} \beta_{l}(\operatorname{InL})^{2}+\frac{1}{2} \beta_{k k}\left(\operatorname{In} K_{i}\right)^{2}+\beta_{l k}\left(\operatorname{In} L_{i}\right)\left(\operatorname{In} K_{i}\right) \\
+\beta_{t l}\left(\operatorname{In} L_{i}\right) t+\beta_{t k}\left(\operatorname{In} K_{i}\right) t+\alpha_{t t} t+\frac{1}{2} \beta_{t t} t^{2}+\left(v_{i t}-u_{i t}\right)----(5)
\end{array}
$$

where $y_{i t}$ is the value-added, $K$ and $L$ are the inputs for capital and labor respectively.

The above specification allows the estimation of both TP in the stochastic frontier and timevarying technical efficiency. N ote that the translog parameterization of this stochastic frontier model allows for non-neutral TP.

TP is neutral if all $\beta_{t}$ 's are equal to zero. The production function reduces to the Cobb-Douglas function with neutral TP if all the âs are equal to zero.

The distribution of technical inefficiency effects, $u_{i t}$ is taken to be the non-negative truncation of the normal distribution $N\left(\mu, \sigma_{u^{2}}\right)$, modeled, following (Battese \& Coelli 1992, Greene 1997, p119), to be the product of an exponential function of time as

$$
u_{i t}=\eta_{t} u_{i}=u_{i} \exp (-\eta[t-T], t \in \gamma(i)
$$

Here, the unknown parameter ç represents the rate of change in technical inefficiency, and the nonnegative random variable ui, is the technical inefficiency effect for thei-th production unit in the last year for the data set. That is, the technical inefficiency effects in earlier periods are deterministic exponential function of the inefficiency effects for the corresponding forms in the final period (i.e. $u_{i T}=u_{i}$, given that data for the $i$-th production unit are available in period $T$ ). $\hat{o}(i)$ is the set of $T$ time periods. So that production unit with a positiveç is likely to improve its level of efficiency over time and vice-verse. A value of $c ̧=0$ implies no time-effect.

Since the estimates of technical efficiency are sensitive to the choice of distribution assumptions, we consider truncated normal distribution for general specifications for one-sided error $u_{i t}$, and halfnormal distribution can be tested by LR test.

Given the estimates of parameters in equation (5) and (6), the technical efficiency level of unit $i$ at timet is then defined as the ratio of the actual output to the potential output,

$\mathrm{TE}_{\mathrm{it}}=\exp \left(-\mathrm{u}_{\mathrm{it}}\right)$

and TEC is the change in TE.

The rate of technological progress is defined by,

$T P_{i t}=\frac{\partial \operatorname{Inf}\left(x_{i t, t}\right)}{\partial t}=\alpha_{t}+\beta_{t t} t+\beta_{t L}\left(\operatorname{In} L_{i}\right)+\beta_{t K}\left(\operatorname{In} K_{i}\right)$ 
that is, the technical change for i-th production unit can be calculated directly from the estimated parameters by evaluating the partial derivative of the production function with respect to time (at a particular date point). However, if technical change is non-neutral then this technical change may vary for different input vectors. Hence, following Coelli, Rao \& Battese (1998), we use the geometric mean between adjacent periods as a proxy,

$T P_{i t}=\left[\left(1+\frac{\partial \operatorname{Inf}\left(x_{i t, t}\right)}{\partial t}\right) *\left(1+\frac{\partial \operatorname{Inf}\left(x_{i t+1, t+1}\right)}{\partial(t+1)}\right]^{1 / 2}-1\right.$

Both $\mathrm{TE}_{\mathrm{it}}$ and $\mathrm{TP}_{\mathrm{it}}$ vary over time and across the production units.

\section{Data Sources and Measurement of Variables}

The main data source is the Annual Survey of Industries (ASI), which is published by the Central Statistical Organization of India. The ASI considers only registered manufacturing sectors. In the ASI, the manufacturing industry is classified into 17 sectors at two-digit industrial classification levels ${ }^{1}$. The ASI data on total output, net value added, gross value added, and wages to employees are in levels at the end of the financial year, and all series are in nominal terms. By using appropriate price index series, we converted the nominal values to the real values, at 1993 constant prices. Although there are some problems with reliability of the ASI, such as variations in coverage, changes in industrial classification, missing variables, and so on, the ASI is the only publicly available source for data on output, employment, compensation, capital stocks, etc.

The period chosen for the analysis in the present study is 1979-80 to 1997-98. Gross value added figures have been used as an index of output. Following Goldar (1986), we preferred gross value added as an index of output in place of net value added because depreciation charges in the Indian industries are known to be highly arbitrary, fixed by income tax authorities and seldom represent actual consumption. However it may be pointed out, however, that from the data available to us it is extremely difficult to make proper estimate of capital consumption. To make correction for nominal gross value added to real gross value added, the yearly current value have been deflated (single

\footnotetext{
${ }^{1}$ ASI consists of 26 sectors in total industry at two-digit classification, but 19 sectors are in manufacturing, i.e., code 20 to 38. we also detect that code 20-21 and 35-36 are the same by definition, which left us with manufacturing sectors.
} 
deflation) by a suitable price index. Single-deflation means the value of output and value of input are deflated by a single price index. Here in this study, nominal gross value added for total manufacturing industry has been deflated by Wholesale price of manufactured products and respective sector specific commodity price index have been deflated for sectoral manufacturing industries. Similarly, wholesale price of manufactured products has been used as a proxy to obtain real gross value added in case of Textile, Machinery and Equipments, and other manufacturing industries.

To construct capital stocks, we used the gross fixed capital formation series, which starts in 1979-80. Obviously, in order to increase the reliability of our initial capital stocks estimates, we would need longer time series. However, in our case this was not possible because of the reclassification of industries in 1970. The standard Perpetual Inventory Method (PIM) is used here to construct the capital stock under a uniform 5\% depreciation rate with 1993-94 as benchmark, i.e.

$K_{i, t+1}=K_{i, t}+I_{i, t+1}-\partial^{*} K_{i, t}$

where $K_{i, t}$ is capital stock of sector $i$ at period $t, I_{i t}$ is capital formation and $\delta$ is depreciation rate. The series on fixed capital has been deflated by the WPI of machinery and machine tools.

Following common practice, the initial capital stock series is initialized by the following equation;

$$
K_{i, 0}=I_{i, 0} /\left(g_{i}+\boldsymbol{\delta}\right)
$$

Where $\mathrm{I}_{\mathrm{i}, 0}$ is the first year investment data available in the sample, $\mathrm{g}_{\mathrm{i}}$ is the average growth in the sample years of investment series and $\delta$ is the depreciation rate. Here, we implicitly assume that no capital stock exists before 1979/80 for all sectors in question. Past studies have shown that given positive rates of depreciation and sufficiently long investment series, the PIM is insensitive to the level of capital used to initialize the series.

The number of workers employed in each sector was for labour input, which is not adjusted for changing quality or skill composition due to lack of consistent data. 


\section{Empirical Results}

The study has estimated the trends of total factor productivity growth, technical progress, and technical efficiency changes in case of two-digit disaggregate manufacturing level during $1980-81$ to $1997-98$. The estimation of parameters in the stochastic frontier model given by equation (5) and (6) are carried out via maximumlikelihood method, using the program FRONTIER 4.1 Coelli, 1996). Further, the decomposition of total factor productivity growth into technical progress, and technical efficiency change has been calculated in case of disaggregate manufacturing level. Besides the intertemporal comparison of growth of TFP, TP, and TEC, an attempt has also been made to see the consistency of the estimates by applying monotonicity and convexity properties of the production theory.

Estimated TFP growth rate are presented in table 1. According to the table 1, the TFP growth rate trend has been increased in most of the industries in period 1997-98 as compared to 1980-81. Sub sectors like wood, textile, leather, other manufacturing, and rubber are having higher growth rate as compared to industry like food processing, beverage and cotton. The highest growth rate is observed for "wood industry" and the lowest growth rate for " cotton industry". From this result, it can be pointed out that investment in social overheads, learning by doing and changes in skill composition (human capital) must have a significant favourable influence on TFP. Also new investments in the new industries like information technology, automobile are already embodied advance technological knowledge. The overall present estimates bring out that the performance of the large-scale sector is better. During this period there must have been a significant improvement in the quality of labour and massive inflow of advanced foreign technology embodied in new capital goods. Table 2 shows the industry-specific technological progress of manufacturing sector in India. The trend of technological progress of almost all the industries either remained the same or has increased. The new industrial policy and the process of economic reforms in Indian 
economy, which were initiated in 1985, may be cited as the most probable reason for this very impressive technological progress. 
Table 1: Average Annual Growth Rates of TFP in Indian Manufacturing Sector (in percentage)

\begin{tabular}{|c|c|c|c|c|c|c|c|c|c|c|c|c|c|c|c|c|c|c|}
\hline & $\begin{array}{c}1980- \\
81\end{array}$ & $\begin{array}{c}1981- \\
82\end{array}$ & $\begin{array}{c}1982- \\
83\end{array}$ & $\begin{array}{c}1983- \\
84\end{array}$ & $\begin{array}{c}1984- \\
85\end{array}$ & $\begin{array}{c}1985- \\
86\end{array}$ & $\begin{array}{c}1986- \\
87\end{array}$ & $\begin{array}{c}1987- \\
88\end{array}$ & $\begin{array}{c}\text { 1988- } \\
89\end{array}$ & $\begin{array}{c}1989- \\
90\end{array}$ & $\begin{array}{c}1990- \\
91\end{array}$ & $\begin{array}{c}\text { 1991- } \\
92\end{array}$ & $\begin{array}{c}1992- \\
93\end{array}$ & $\begin{array}{c}1993- \\
94\end{array}$ & $\begin{array}{c}1994- \\
95\end{array}$ & $\begin{array}{c}1995- \\
96\end{array}$ & $\begin{array}{c}\text { 1996- } \\
97\end{array}$ & $\begin{array}{c}1997- \\
98\end{array}$ \\
\hline $20-21$ & 7.0 & 7.0 & 7.1 & 7.4 & 7.6 & 7.7 & 7.8 & 7.8 & 7.8 & 7.8 & 7.7 & 7.8 & 7.7 & 7.7 & 7.7 & 7.7 & 7.7 & 7.7 \\
\hline 22 & 8.7 & 8.7 & 8.7 & 8.7 & 8.9 & 9.2 & 9.1 & 9.0 & 9.0 & 8.9 & 8.8 & 8.8 & 8.8 & 8.8 & 8.8 & 8.8 & 8.8 & 8.8 \\
\hline 23 & 6.8 & 6.9 & 7.0 & 7.0 & 7.1 & 7.3 & 7.4 & 7.4 & 7.6 & 7.6 & 7.6 & 7.7 & 7.7 & 7.7 & 7.7 & 7.7 & 7.6 & 7.6 \\
\hline 24 & 9.9 & 9.9 & 9.8 & 9.8 & 9.8 & 9.8 & 9.9 & 9.9 & 9.9 & 10.0 & 10.0 & 10.0 & 10.1 & 10.0 & 10.0 & 9.9 & 9.8 & 9.9 \\
\hline 25 & 9.3 & 9.5 & 9.6 & 9.7 & 9.7 & 9.8 & 10.1 & 10.2 & 10.3 & 10.3 & 10.3 & 10.4 & 10.5 & 10.6 & 10.7 & 10.4 & 10.3 & 10.5 \\
\hline 26 & 11.9 & 12.1 & 12.2 & 12.2 & 12.2 & 12.2 & 12.4 & 12.3 & 12.2 & 12.1 & 12.0 & 12.0 & 12.0 & 11.7 & 11.4 & 11.3 & 11.3 & 11.3 \\
\hline 27 & 12.8 & 12.9 & 13.0 & 13.2 & 13.3 & 13.4 & 13.6 & 13.7 & 13.8 & 13.9 & 14.1 & 14.3 & 14.3 & 14.3 & 14.4 & 14.4 & 14.4 & 14.5 \\
\hline 28 & 9.8 & 9.8 & 9.8 & 9.8 & 9.9 & 10.0 & 10.1 & 10.2 & 10.2 & 10.3 & 10.3 & 10.3 & 10.3 & 10.3 & 10.3 & 10.2 & 10.2 & 10.3 \\
\hline 29 & 12.6 & 12.7 & 12.7 & 12.8 & 12.8 & 12.7 & 12.8 & 12.8 & 12.7 & 12.5 & 12.5 & 12.5 & 12.5 & 12.5 & 12.5 & 12.4 & 12.5 & 12.6 \\
\hline 30 & 9.9 & 10.0 & 10.1 & 10.2 & 10.2 & 10.3 & 10.4 & 10.4 & 10.4 & 10.5 & 10.6 & 10.7 & 10.7 & 10.7 & 10.7 & 10.6 & 10.6 & 10.7 \\
\hline 31 & 11.8 & 11.9 & 11.9 & 12.0 & 12.1 & 12.2 & 12.3 & 12.3 & 12.3 & 12.3 & 12.3 & 12.3 & 12.3 & 12.3 & 12.4 & 12.4 & 12.3 & 12.4 \\
\hline 32 & 9.3 & 9.3 & 9.2 & 9.2 & 9.2 & 9.3 & 9.3 & 9.4 & 9.4 & 9.5 & 9.5 & 9.5 & 9.5 & 9.6 & 9.6 & 9.6 & 9.6 & 9.7 \\
\hline 33 & 9.3 & 9.3 & 9.4 & 9.4 & 9.4 & 9.5 & 9.6 & 9.7 & 9.8 & 9.9 & 9.9 & 10.0 & 10.0 & 10.0 & 10.1 & 10.1 & 10.1 & 10.2 \\
\hline 34 & 10.5 & 10.7 & 10.7 & 10.8 & 10.9 & 10.9 & 11.1 & 11.1 & 11.0 & 11.0 & 11.0 & 11.1 & 11.1 & 11.1 & 11.1 & 11.1 & 10.9 & 11.0 \\
\hline $35-36$ & 9.5 & 9.6 & 9.6 & 9.6 & 9.7 & 9.8 & 9.9 & 10.0 & 10.0 & 10.0 & 10.1 & 10.1 & 10.2 & 10.2 & 10.3 & 10.2 & 10.2 & 10.4 \\
\hline 38 & 12.9 & 13.1 & 13.2 & 13.2 & 13.3 & 13.4 & 13.5 & 13.5 & 13.5 & 13.5 & 13.5 & 13.5 & 13.5 & 13.4 & 13.4 & 13.3 & 13.3 & 13.4 \\
\hline
\end{tabular}


Table 2: Industry-specific Technological Progress of Manufacturing Sector in India (in percentage)

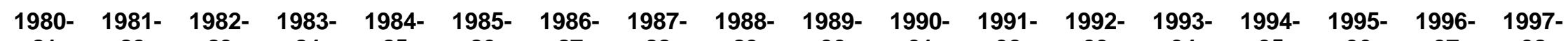

\begin{tabular}{ccccccccccccccccccc} 
& $\mathbf{8 1}$ & $\mathbf{8 2}$ & $\mathbf{8 3}$ & $\mathbf{8 4}$ & $\mathbf{8 5}$ & $\mathbf{8 6}$ & $\mathbf{8 7}$ & $\mathbf{8 8}$ & $\mathbf{8 9}$ & $\mathbf{9 0}$ & $\mathbf{9 1}$ & $\mathbf{9 2}$ & $\mathbf{9 3}$ & $\mathbf{9 4}$ & $\mathbf{9 5}$ & $\mathbf{9 6}$ & $\mathbf{9 7}$ & $\mathbf{9 8}$ \\
\cline { 2 - 12 } $\mathbf{2 0}$ & $\mathbf{8 . 8}$ & 8.8 & 9.0 & 9.3 & 9.6 & $\mathbf{9 . 7}$ & $\mathbf{9 . 9}$ & $\mathbf{9 . 9}$ & 10.0 & 10.0 & 10.0 & 10.1 & 10.2 & 10.2 & 10.3 & 10.3 & 10.4 & 10.5 \\
$\mathbf{2 2}$ & 10.4 & 10.4 & 10.4 & 10.5 & 10.8 & 11.1 & 11.1 & 11.0 & 11.0 & 11.0 & 11.0 & 11.1 & 11.1 & 11.2 & 11.3 & 11.3 & 11.4 & 11.4 \\
$\mathbf{2 3}$ & 9.0 & 9.2 & 9.3 & 9.4 & 9.6 & 9.8 & 10.0 & 10.1 & 10.3 & 10.4 & 10.5 & 10.6 & 10.8 & 10.8 & 10.9 & 11.0 & 11.0 & 11.1 \\
$\mathbf{2 4}$ & 11.5 & 11.5 & 11.5 & 11.5 & 11.6 & 11.7 & 11.8 & 11.8 & 11.9 & 12.1 & 12.1 & 12.2 & 12.3 & 12.3 & 12.3 & 12.3 & 12.3 & 12.5 \\
$\mathbf{2 5}$ & 10.9 & 11.1 & 11.3 & 11.4 & 11.4 & 11.6 & 11.9 & 12.1 & 12.2 & 12.3 & 12.4 & 12.5 & 12.6 & 12.8 & 13.0 & 12.8 & 12.8 & 13.0 \\
$\mathbf{2 6}$ & 12.5 & 12.7 & 12.8 & 12.8 & 12.9 & 12.9 & 13.1 & 13.1 & 13.0 & 12.9 & 12.8 & 12.8 & 12.8 & 12.5 & 12.2 & 12.2 & 12.2 & 12.2 \\
$\mathbf{2 7}$ & 12.9 & 13.0 & 13.1 & 13.2 & 13.4 & 13.5 & 13.7 & 13.8 & 13.9 & 14.0 & 14.2 & 14.4 & 14.4 & 14.4 & 14.5 & 14.5 & 14.6 & 14.6 \\
$\mathbf{2 8}$ & 11.2 & 11.2 & 11.3 & 11.3 & 11.5 & 11.6 & 11.8 & 11.8 & 11.9 & 12.1 & 12.2 & 12.2 & 12.3 & 12.3 & 12.4 & 12.3 & 12.4 & 12.6 \\
$\mathbf{2 9}$ & 13.4 & 13.5 & 13.6 & 13.6 & 13.7 & 13.7 & 13.7 & 13.8 & 13.7 & 13.5 & 13.5 & 13.6 & 13.6 & 13.7 & 13.7 & 13.6 & 13.7 & 13.9 \\
$\mathbf{3 0}$ & 10.4 & 10.5 & 10.6 & 10.7 & 10.8 & 10.8 & 10.9 & 11.0 & 11.0 & 11.1 & 11.3 & 11.3 & 11.3 & 11.3 & 11.4 & 11.3 & 11.3 & 11.4 \\
$\mathbf{3 1}$ & 11.8 & 11.9 & 11.9 & 12.0 & 12.2 & 12.2 & 12.3 & 12.3 & 12.3 & 12.3 & 12.3 & 12.4 & 12.4 & 12.4 & 12.4 & 12.4 & 12.4 & 12.5 \\
$\mathbf{3 2}$ & 10.8 & 10.8 & 10.8 & 10.8 & 10.9 & 11.0 & 11.1 & 11.2 & 11.3 & 11.4 & 11.4 & 11.5 & 11.6 & 11.7 & 11.8 & 11.8 & 11.9 & 12.1 \\
$\mathbf{3 3}$ & 10.2 & 10.2 & 10.3 & 10.4 & 10.4 & 10.5 & 10.7 & 10.8 & 10.9 & 11.0 & 11.1 & 11.2 & 11.2 & 11.3 & 11.4 & 11.4 & 11.5 & 11.7 \\
$\mathbf{3 4}$ & 11.6 & 11.8 & 11.9 & 12.0 & 12.1 & 12.2 & 12.4 & 12.4 & 12.4 & 12.4 & 12.4 & 12.5 & 12.6 & 12.7 & 12.7 & 12.7 & 12.6 & 12.7 \\
$\mathbf{3 5 - 3 6}$ & 10.6 & 10.7 & 10.7 & 10.8 & 10.9 & 11.0 & 11.1 & 11.2 & 11.3 & 11.4 & 11.5 & 11.6 & 11.6 & 11.7 & 11.8 & 11.8 & 11.8 & 12.0 \\
$\mathbf{3 7}$ & 10.3 & 10.4 & 10.4 & 10.5 & 10.6 & 10.8 & 10.9 & 11.0 & 11.1 & 11.2 & 11.3 & 11.4 & 11.5 & 11.5 & 11.6 & 11.5 & 11.5 & 11.7 \\
$\mathbf{3 8}$ & 13.2 & 13.4 & 13.4 & 13.5 & 13.6 & 13.7 & 13.7 & 13.8 & 13.8 & 13.8 & 13.8 & 13.9 & 13.9 & 13.8 & 13.8 & 13.7 & 13.7 & 13.8
\end{tabular}

Source: Annual Survey of Industries (ASI) and authors' own calculation 
Fig.1: Productivity growth, Technological Progress, and Technical Efficiency Change in aggregate manufacturing sector

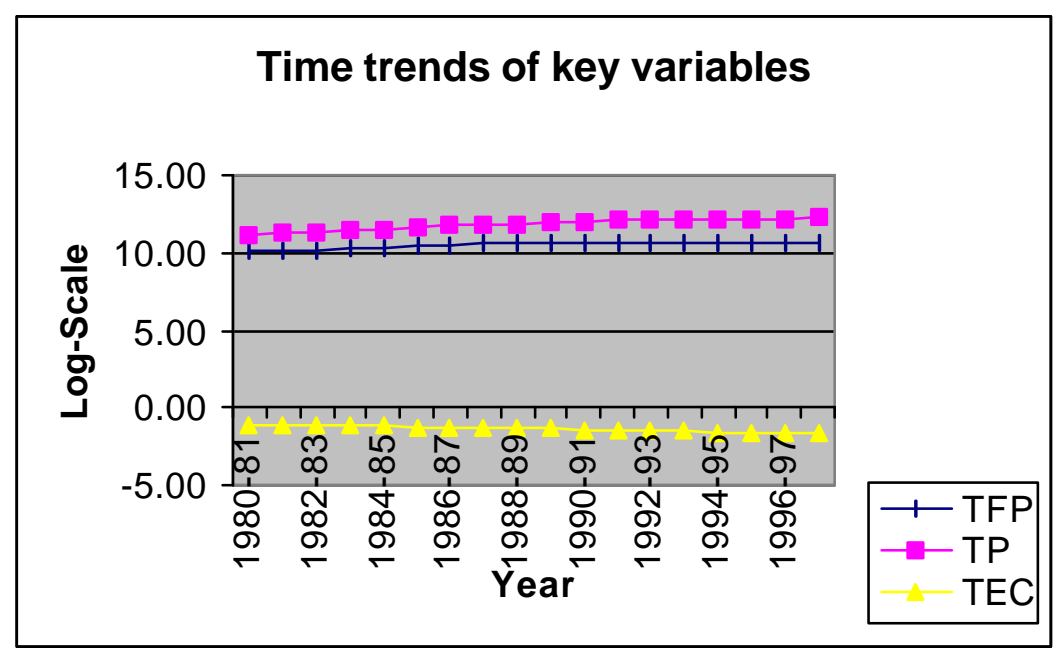

Source: ASI and authors' own calculations.

Some of the provisions of the new policy were:(i) It abolished industrial licenses for all projects, except for a short list of 18 specified industries related to (a) securities and strategic areas (b) hazardous chemicals (c) items of elitist consumption. (ii) It removed the asset limits for MRTP totally. (iii) It raised the limit for foreign equity holding 40 per cent to 51 per cent. (iv) Industry reserved for the small-scale sectors would continue to be so reserved. (v) The policy promised social security mechanisms to protect workers interest in affected public sector enterprises.

Table 3 gives the time-variant industry-specific predictors of technical efficiency change based on equation (7). The hypothesis specifying that the technical inefficiency effects $\left(\mathrm{u}_{\mathrm{it}}\right)$ are time invariant since the null hypothesis $\mathrm{H}_{\mathrm{b}}: \mu=0$ is not rejected by the data. On the whole, the assumptions that technical inefficiency effects $u_{i t}$ are time varying and follow truncated normal distribution are not accepted by the data. From this table, the results show that there are negative trend in technical efficiency in all the industries of Indian economy. Technical efficiency is directly related to technical know-how and socio economic characteristics of the industrial workers. Any variations in these attributes tend to cause differences in technical efficiency amongst workers, which then lead to variations in total productivity achieved by them. There are some probable factors that affecting the efficiency of the workers in case of Indian economy. Some factors are 
Table 3: Industry-specific Technical Efficiency Change of Manufacturing Sector in India (in percentage)

\begin{tabular}{|c|c|c|c|c|c|c|c|c|c|c|c|c|c|c|c|c|c|c|}
\hline & $\begin{array}{c}1980- \\
81\end{array}$ & $\begin{array}{c}1981- \\
82\end{array}$ & $\begin{array}{c}1982- \\
83\end{array}$ & $\begin{array}{c}1983- \\
84\end{array}$ & $\begin{array}{c}1984- \\
85\end{array}$ & $\begin{array}{c}1985- \\
86\end{array}$ & $\begin{array}{c}1986- \\
87\end{array}$ & $\begin{array}{c}1987- \\
88\end{array}$ & $\begin{array}{c}1988- \\
89\end{array}$ & $\begin{array}{c}1989- \\
90\end{array}$ & $\begin{array}{c}1990- \\
91\end{array}$ & $\begin{array}{c}1991- \\
92\end{array}$ & $\begin{array}{c}1992- \\
93\end{array}$ & $\begin{array}{c}1993- \\
94\end{array}$ & $\begin{array}{c}1994- \\
95\end{array}$ & $\begin{array}{c}1995- \\
96\end{array}$ & $\begin{array}{c}1996- \\
97\end{array}$ & 1997-98 \\
\hline $20-21$ & -1.8 & -1.8 & -1.9 & -1.9 & -2.0 & -2.0 & -2.1 & -2.1 & -2.2 & -2.2 & -2.3 & -2.4 & -2.4 & -2.5 & -2.6 & -2.6 & -2.7 & -2.8 \\
\hline 22 & -1.7 & -1.7 & -1.8 & -1.8 & -1.9 & -1.9 & -2.0 & -2.0 & -2.1 & -2.1 & -2.2 & -2.3 & -2.3 & -2.4 & -2.4 & -2.5 & -2.6 & -2.7 \\
\hline 23 & -2.2 & -2.3 & -2.3 & -2.4 & -2.5 & -2.5 & -2.6 & -2.7 & -2.8 & -2.8 & -2.9 & -3.0 & -3.1 & -3.1 & -3.2 & -3.3 & -3.4 & -3.5 \\
\hline 24 & -1.6 & -1.7 & -1.7 & -1.8 & -1.8 & -1.9 & -1.9 & -2.0 & -2.0 & -2.1 & -2.1 & -2.2 & -2.2 & -2.3 & -2.4 & -2.4 & -2.5 & -2.6 \\
\hline 25 & -1.6 & -1.6 & -1.7 & -1.7 & -1.7 & -1.8 & -1.8 & -1.9 & -1.9 & -2.0 & -2.1 & -2.1 & -2.2 & -2.2 & -2.3 & -2.4 & -2.4 & -2.5 \\
\hline 26 & -0.6 & -0.6 & -0.6 & -0.6 & -0.7 & -0.7 & -0.7 & -0.7 & -0.7 & -0.8 & -0.8 & -0.8 & -0.8 & -0.8 & -0.9 & -0.9 & -0.9 & -0.9 \\
\hline 27 & -0.1 & -0.1 & -0.1 & -0.1 & -0.1 & -0.1 & -0.1 & -0.1 & -0.1 & -0.1 & -0.1 & -0.1 & -0.1 & -0.1 & -0.1 & -0.1 & -0.1 & -0.1 \\
\hline 28 & -1.4 & -1.4 & -1.5 & -1.5 & -1.6 & -1.6 & -1.6 & -1.7 & -1.7 & -1.8 & -1.8 & -1.9 & -1.9 & -2.0 & -2.0 & -2.1 & -2.2 & -2.2 \\
\hline 29 & -0.8 & -0.8 & -0.9 & -0.9 & -0.9 & -0.9 & -1.0 & -1.0 & -1.0 & -1.0 & -1.1 & -1.1 & -1.1 & -1.2 & -1.2 & -1.2 & -1.3 & -1.3 \\
\hline 30 & -0.5 & -0.5 & -0.5 & -0.5 & -0.5 & -0.5 & -0.6 & -0.6 & -0.6 & -0.6 & -0.6 & -0.6 & -0.7 & -0.7 & -0.7 & -0.7 & -0.7 & -0.8 \\
\hline 31 & 0.0 & 0.0 & 0.0 & 0.0 & -0.1 & -0.1 & -0.1 & -0.1 & -0.1 & -0.1 & -0.1 & -0.1 & -0.1 & -0.1 & -0.1 & -0.1 & -0.1 & -0.1 \\
\hline 32 & -1.5 & -1.5 & -1.6 & -1.6 & -1.7 & -1.7 & -1.8 & -1.8 & -1.8 & -1.9 & -2.0 & -2.0 & -2.1 & -2.1 & -2.2 & -2.2 & -2.3 & -2.4 \\
\hline 33 & -0.9 & -0.9 & -0.9 & -1.0 & -1.0 & -1.0 & -1.1 & -1.1 & -1.1 & -1.1 & -1.2 & -1.2 & -1.2 & -1.3 & -1.3 & -1.3 & -1.4 & -1.4 \\
\hline 34 & -1.1 & -1.1 & -1.1 & -1.2 & -1.2 & -1.2 & -1.3 & -1.3 & -1.3 & -1.4 & -1.4 & -1.5 & -1.5 & -1.5 & -1.6 & -1.6 & -1.7 & -1.7 \\
\hline $35-36$ & -1.1 & -1.1 & -1.1 & -1.2 & -1.2 & -1.2 & -1.3 & -1.3 & -1.3 & -1.4 & -1.4 & -1.4 & -1.5 & -1.5 & -1.6 & -1.6 & -1.6 & -1.7 \\
\hline 37 & -1.1 & -1.2 & -1.2 & -1.2 & -1.3 & -1.3 & -1.3 & -1.4 & -1.4 & -1.5 & -1.5 & -1.5 & -1.6 & -1.6 & -1.7 & -1.7 & -1.8 & -1.8 \\
\hline 38 & -0.3 & -0.3 & -0.3 & -0.3 & -0.3 & -0.3 & -0.3 & -0.3 & -0.3 & -0.3 & -0.3 & -0.3 & -0.3 & -0.4 & -0.4 & -0.4 & -0.4 & -0.4 \\
\hline
\end{tabular}

Source: Annual Survey of Industries (ASI) and authors' own calculation 
associated with technical knowledge and some socio economic variables. In India, except heavy industries, other industries are basically producing output by labour intensive technique. So most of the workers are unskilled and very limited knowledge about how to use best practice technology. Similarly socio economics variables like age of the workers, child labour, non-firm income of the worker, health condition, poverty, bureaucratic controls are assumed to be relevant for the negative TECs. The result from the table implies that by adopting best practices the Indian manufacturing sector cannot reduce the inputs like labour and capital.

Table 4: Panel Estimation of Stochastic Production Frontier and Technical Inefficiency Model

\begin{tabular}{|l|l|l|l|}
\hline \multicolumn{1}{|c|}{ Variable } & \multicolumn{1}{c|}{ Co-efficient } & \multicolumn{1}{c|}{ Standard-error } & \multicolumn{1}{c|}{ t-statistics } \\
\hline Constant & 0.6859 & 0.0377 & 18.1764 \\
\hline InL & 0.7348 & 0.0891 & 8.2435 \\
\hline InK & 0.3749 & 0.0430 & 8.7263 \\
\hline$(\mathrm{InL})^{2}$ & -0.0485 & 0.1447 & -0.3353 \\
\hline$(\mathrm{InK})^{2}$ & -0.0377 & 0.0599 & -0.6288 \\
\hline$(\mathrm{InL})(\mathrm{InK})$ & -0.1613 & 0.0885 & -1.8218 \\
\hline$(\mathrm{InL}) \mathrm{t}$ & -0.0161 & 0.0161 & -1.0043 \\
\hline$(\mathrm{InK}) \mathrm{t}$ & 0.0011 & 0.0100 & 0.1068 \\
\hline $\mathrm{T}$ & 0.1183 & 0.0089 & 13.3322 \\
\hline $\mathrm{T}^{2}$ & 0.0012 & 0.0020 & 0.5671 \\
\hline$\sigma^{2}$ & 0.0864 & 0.0124 & 6.9639 \\
\hline$\gamma$ & 0.7409 & 0.0402 & 18.4172 \\
\hline$\mu$ & 0.5060 & 0.1346 & 3.7601 \\
\hline$\eta$ & -0.0269 & 0.0070 & -3.8455 \\
\hline Log-likelihood & 123.2811 & & \\
\hline LR & 255.7386 & $\mathrm{df}=3$ & \\
\hline No of observations & 323 & & \\
\hline Sou Angan & & \\
\hline
\end{tabular}

Source: Annual Survey of Industries (ASI) and authors' own calculation.

Table 4 shows the result of stochastic translog frontier production function in which the technical inefficiency affects $\mathrm{U}_{i t}$, have the time varying structure and follow truncated normal distribution. The estimate of $\gamma$ which is the ratio of the variance of firm-specific performance of technical efficiency to total variance of output is statistically significant at 1 per cent level in Indian manufacturing sector. This implies that the variation in productivity performances among the industries not due to statistical chance factor but principally to individual technical efficiency differences.

\section{Decomposition of TFP Growth}

The estimates of Technical Efficiency (TE) and Technological Progress (TP) are derived by equation (3), and the sectoral TFP growth is not calculated as a residual but is obtained by summing changes in TE and TP. The eight column of table 5 shows that the 
TFP growth stagnated or increased in most of the industries in 1997-98 as compared to 1980-81. Some authors argue that the dynamism happened because of institutional reforms started in early 1980s and results show a strong productivity growth. Nevertheless, the decomposition of TFP growth into technical efficiency change and technological progress does help to understand these changes. Here the results reveal that output growth, induced by reforms, can be attributable to productivity growth, of which technological progress is the most dominant component. Negative sign for technical efficiency change indicate that capacity realization declined from period to the later period. Within manufacturing sector, there is heterogeneity among the industries on the basis of technical efficiency change. Industries such as chemical, wood, rubber, other manufacturings are little efficient as compare to traditional sectors like jute, beverage, food processing, cotton, and wool. 
Table 5: Decomposition of Annual and Average TFP Growth Rates of Indian Manufacturing Sector (\%)

\begin{tabular}{|c|c|c|c|c|c|c|c|c|c|c|c|c|}
\hline \multirow{2}{*}{$\begin{array}{l}\text { Industry } \\
\text { Code }\end{array}$} & \multicolumn{3}{|c|}{ 1980-81 } & \multicolumn{3}{|c|}{ 1990-91 } & \multicolumn{3}{|c|}{ 1997-98 } & \multicolumn{3}{|c|}{$1980-98$} \\
\hline & $\begin{array}{l}\text { TFP } \\
\text { Growth }\end{array}$ & $\mathbf{T P}$ & TEC & $\begin{array}{l}\text { TFP } \\
\text { Growth }\end{array}$ & $\mathbf{T P}$ & TEC & $\begin{array}{l}\text { TFP } \\
\text { Growth }\end{array}$ & $\mathbf{T P}$ & TEC & $\begin{array}{l}\text { TFP } \\
\text { Growth }\end{array}$ & TP & TEC \\
\hline 20-21 & 7.0 & 8.8 & -1.8 & 7.7 & 10.0 & -2.3 & 7.7 & 10.5 & -2.8 & 7.59 & 9.8 & -2.2 \\
\hline 23 & 6.8 & 9.0 & -2.2 & 7.6 & 10.5 & -2.9 & 7.6 & 11.1 & -3.5 & 7.39 & 10.2 & -2.8 \\
\hline 24 & 9.9 & 11.5 & -1.6 & 10.0 & 12.1 & -2.1 & 9.9 & 12.5 & -2.6 & 9.90 & 12.0 & -2.1 \\
\hline 25 & 9.3 & 10.9 & -1.6 & 10.3 & 12.4 & -2.1 & 10.5 & 13.0 & -2.5 & 10.13 & 12.1 & -2.0 \\
\hline 26 & 11.9 & 12.5 & -0.6 & 12.0 & 12.8 & -0.8 & 11.3 & 12.2 & -0.9 & 11.92 & 12.7 & -0.8 \\
\hline 27 & 12.8 & 12.9 & -0.1 & 14.1 & 14.2 & -0.1 & 14.5 & 14.6 & -0.1 & 13.78 & 13.9 & -0.1 \\
\hline 28 & 9.8 & 11.2 & -1.4 & 10.3 & 12.2 & -1.8 & 10.3 & 12.6 & -2.2 & 10.13 & 11.9 & -1.8 \\
\hline 29 & 12.6 & 13.4 & -0.8 & 12.5 & 13.5 & -1.1 & 12.6 & 13.9 & -1.3 & 12.61 & 13.6 & -1.0 \\
\hline 30 & 9.9 & 10.4 & -0.5 & 10.6 & 11.3 & -0.6 & 10.7 & 11.4 & -0.8 & 10.44 & 11.0 & -0.6 \\
\hline 31 & 11.8 & 11.8 & 0.0 & 12.3 & 12.3 & -0.1 & 12.4 & 12.5 & -0.1 & 12.20 & 12.3 & -0.1 \\
\hline 32 & 9.3 & 10.8 & -1.5 & 9.5 & 11.4 & -2.0 & 9.7 & 12.1 & -2.4 & 9.43 & 11.3 & -1.9 \\
\hline 34 & 10.5 & 11.6 & -1.1 & 11.0 & 12.4 & -1.4 & 11.0 & 12.7 & -1.7 & 10.95 & 12.3 & -1.4 \\
\hline 35-36 & 9.5 & 10.6 & -1.1 & 10.1 & 11.5 & -1.4 & 10.4 & 12.0 & -1.7 & 9.95 & 11.3 & -1.4 \\
\hline 37 & 9.1 & 10.3 & -1.1 & 9.8 & 11.3 & -1.5 & 9.9 & 11.7 & -1.8 & 9.63 & 11.1 & -1.5 \\
\hline 38 & 12.9 & 13.2 & -0.3 & 13.5 & 13.8 & -0.3 & 13.4 & 13.8 & -0.4 & 13.36 & 13.7 & -0.3 \\
\hline
\end{tabular}

Source: Annual Survey of Industries (ASI) and authors' own calculation. 


\section{Conclusions}

In this paper, we analyze the technical efficiency change and role of productivity change in economic growth by using stochastic production frontier to two-digit registered manufacturing sector in India. The stochastic frontier production function developed by (Battese and Coelli, (1992) allowing time varying technical inefficiency has been considered and tested assumption regarding the parameters of time varying technical inefficiency.

Using the translog approaches to model based on panel data it estimates the parameters of production function and rate of technological progress and technical efficiency change for each industry group. The TFP is calculated from the estimated production function and the growth rate seems to have improved in a large number of industries during 198081 to 1997-98. In this paper, the two TFP components- technical efficiency change and technological progress estimated separately. The decomposition results show that TFPs are not mainly driven by efficiency change but by technological progress. Finally, the measures of TFP growth components not only provide more insights and better understanding of the dynamic nature of the production process, but also have important policy implication. For example, policy action intended to improve TFP growth rate might be misdirected if they focus on accelerating the rate of innovation in circumstances where the cause of total factor productivity could be due to the low rate of technology diffusion (technical inefficiency), which is really happened in case of Indian manufacturing sector. Although various industrial policy resolutions and five-year plans reveals that the importance and contribution of efficiency in industrial growth has been neglected or given second priority in the framework of industrial development strategy. In this direction, Govt. should take some action to improve productivity efficiency of manufacturing sector especially in case of industrially backward states. Once efficiency will increase, it may enhance our competitiveness by achieving potential output. 


\section{Appendix:}

\section{Classification of Industries}

The database of the study is drawn from Annual Survey of Industries (ASI), which based on the National Industrial Classification NIC-1987.

\begin{tabular}{|l|l|}
\hline $\begin{array}{l}\text { Two-digit } \\
\text { Industry Code }\end{array}$ & Name of the Industry \\
\hline $20-21$ & Food Products \\
\hline 22 & Beverages \\
\hline 23 & Cotton Textiles \\
\hline 24 & Woolen Textiles \\
\hline 25 & Jute Textiles \\
\hline 26 & Textiles Products \\
\hline 27 & Wood Products \\
\hline 28 & Newspaper Products \\
\hline 29 & Leather Products \\
\hline 30 & Chemical Products \\
\hline 31 & $\begin{array}{l}\text { Rubber, Petroleum, and } \\
\text { Coal products }\end{array}$ \\
\hline 32 & Non-metallic Minerals \\
\hline 33 & Basic Metals \\
\hline 34 & Metal Products \\
\hline $35-36$ & Machinery (other prds.) \\
\hline 37 & Transport and Parts \\
\hline 38 & Other Manufacturing \\
\hline
\end{tabular}

\section{Testing Monotonicity \& Concavity of the Estimated Function}

It is at this point that a criterion to evaluated the model is introduced, that of consistency of the estimates with the properties of production theory. We obtain estimates of production elasticities and evaluate monotonicity and concavity ex-post, both for the sample mean and for every sample point.

The output elasticities for each of the inputs, calculated from the translog coefficients, at the variable means, are of interest. These elasticities with respect to the inputs, $\mathrm{x}_{\mathrm{j}}$, for the translog is

$$
e_{j}=\partial \ln y_{i} / \partial \ln x_{j i}=\alpha_{j}+\beta_{j j} \ln x_{j}+\sum_{j=1}^{J-1} \beta_{j l} \ln x_{j}+\beta_{j t} t
$$


Since we have already mean-corrected the data prior to the estimation, the estimated firstorder parameters in the translog function can be directly interpreted as estimates of the production elasticities, evaluated at the sample means.

One of the long established criticisms of the structure of production and its inefficiencies has been the size of production-units in estimation. Therefore, a measure of the economies of scale in production is computed. For non-homogeneous functions such as the translog, the function coefficient is not invariant with respect to initial input levels, and is the sum of the elasticities of each inputs, that is,

$$
e_{i}=\sum_{j} e_{j}=\frac{\partial \ln f\left(x_{i t, t}\right)}{\partial \ln x_{i t}}
$$

calculated at the mean from the maximum likelihood estimators and used to test for returns to scale.

From Table 6, one can see that our estimated parameter satisfy both monotonicity and quasi-curvature conditions so that the estimated parameters are reliable.

Table 6: Elasticities and Percentage of monotonicity and concavity violations

\begin{tabular}{|l|l|l|l|l|}
\hline & Labour & Capital & RTS & \\
\hline Elasticity at Sample Mean & 0.7348 & 0.3749 & 1.1097 & \\
\hline $\begin{array}{l}\text { Violation of positive } \\
\text { elasticity (for every data } \\
\text { point) }\end{array}$ & $0 \%$ & $0 \%$ & & \\
\hline & $\mathrm{H} 11$ & $\mathrm{H} 22$ & $\mathrm{Pm} 1$ & $\mathrm{Pm} 2$ \\
\hline $\begin{array}{l}\text { Violation of concavity (for } \\
\text { every data point) }\end{array}$ & $11.76 \%$ & $0 \%$ & $11.76 \%$ & $32.82 \%$ \\
\hline $\begin{array}{l}\text { Violation of quasi-concavity } \\
\text { (for every data point) }\end{array}$ & & & $0 \%$ & $0 \%$ \\
\hline
\end{tabular}

Notes: H11, H22 are the diagonal elements of Hessian matrix.

$\mathrm{Pm} 1, \mathrm{Pm} 2$ are the principle minors. 


\section{References:}

Aggarwal, A.K \& Ganesh kumar (1991), “ Indian Manufacturing Industry: Verdoorn's Law Revisited". Indian Economic Journal, Vol.39 (2), pp. 61-81.

Ahluwalia, I.J (1991), " Productivity and Growth in Indian Manufacturing”. Oxford University Press, Delhi.

Aigner, Dennis J., Lovell, C.A.Knox \& Schmidt, Peter (1977), “Formulation and Estimation of Stochastic Frontier Production Function Models". Journal of Econometrics, Vol.6(1),pp.21-37.

Battese, G.E.\& Coelli, T.J (1992), “ Frontier Production Functions, Technical Efficiency and Panel Data: With Application to Paddy Farmers in India". Journal of Productivity Analysis, Vol. 3, pp.153-169.

Blalkrishnan, P \& K. Pushpangadan (1994), “ Total Factor Productivity Growth in Manufacturing Industry: A Fresh Look”. Economic and Political Weekly, July 30, PP. $2028-2035$.

Coelli, T.J (1996), “ A Guide to FRONTIER Version 4.1: A Computer Programme for Stochastic Frontier Production and Cost Function Estimation”. CEPA working Papers, No.7/96, Center for Efficiency and Productivity Analysis, University of New England, Australia.

Coelli, T.J., Rao, D.S.Prasad \& Battese, G.E (1998), “ An Introduction to Efficiency and Productivity Analysis". Kluwer Academic Publishers.

Goldar, B (1986), “ Productivity Growth in Indian Industry”. Allied Publishers, New Delhi.

Greene, William H (1997), “Frontier Production Function” in M.Hashem Pesaran \& Peter Schmidt (eds), Handbook of Applied Econometrics, Volume II:

Microeconomics, pp.81-166, Blackwell Publishers.

Joshi, Vijay, and I.M.D.Little (1996), “ Indian Economic Reforms 1991-2001”. Oxford: Clarendon Press.

Kumar Sunil (2002), "Regional Variations in Labour Productivity Growth in Indian Manufacturing Sector”. Anvesak, Vol.32 (2), pp. 111 - 136.

Mitra, A (1999), “ Total Factor Productivity Growth and Technical Efficiency in Indian Industries: A Study Based on Panel Data for Fifteen Major States". Working paper, no. E/ 203/ 99. Institute of Economic Growth, Delhi.

Nishimizu, Mieko \& Page, J,M (1982), “ Total Factor Productivity Growth, Technological Progress and Technical Efficiency Change: Dimensions of Productivity Change in Yugoslavia, 1965-78”. Economic Journal, Vol.92(368),pp.920-936.

Rao Mohan, J (1996), “ Manufacturing Productivity Growth: Method and Measurement”. Economic and Political Weekly, November 2, pp. 2927 - 2936. 
Srinivasan, T.N (1996), “ Indian Economic Reforms: Background, Rationale, Achievements, and Future Prospects". New Haven, Yale University.

Upender, M (1996), "Elasticity of Labour Productivity in Indian manufacturing".

Economic and Political Weekly, Vol.31 (21), pp. M-7 - M -10. 